\title{
EMBODYING BORDERS AND PERFORMING CONFLICTING IDENTITIES IN SOME POLISH FAMILY NARRATIVES
}

\section{NICOLETTA DIASIO}

The article presents an anthropological research on family narratives on memory and identities in Warsaw, as they are made in social bodily practices. Questioning the social construction of family resemblances, it points out the changing idea of "Polishness", the role of women's activities and feminine blood in transmitting this belonging, but also a long-lasting imaginary, sustained by family memory, relating to a multilingual and multicultural Poland. Thus, the body is the support of performing plural identities between naturalization and historicization.

Keywords: family resemblance, memory, identity, East, West.
Članek predstavlja antropološko raziskavo družinskih pripovedi o spominih in identiteti $v$ Varšavi, kakor se oblikujejo v socialnih telesnih praksah. Ob prepraševanju družbene konstrukcije družinskih podobnosti kaže na spremenljivo zamisel o "poljskosti", o vlogi ženskih aktivnosti in ženskega sorodstva pri posredovanju pripadnosti, pa tudi o dolgotrajnem imaginariju, ki ga podpira družinski spomin, povezan z večjezično in večkulturno Poljsko. Tako telo podpira uprizarjanje pluralnih identitet med naturalizacijo in zgodovinjenjem.

Ključne besede: družinske podobnosti, spomin, identiteta, Vzhod, Zahod.

The question of memory and belonging is at the core of producing and performing identity in a country "ceaselessly out of itself, in exile or in dreams" (Krauze 1990: 12). ${ }^{1}$ In Hanna Krall's heart-gripping novel, an old merchant from Samarqand asks a Polish woman: Where do you come from? - Not getting her answer, he insisted: From where? But where is that? - In Europe, between Germany and Russia. He pondered for a moment, then shaking his head: "it's not possible, there's no room left over there. - Indeed, she assented. - And this is where I come from. (Krall 1994: 137-138)

How do inhabitants of the thresholds construe this in-betweenness? Is this identity performed through the mediating paradigm of Central Europe? Is it narrated by the mean of the East-versus-west opposition? If these different positions divide Poland's debates about identity (Milosz 1964; Konwicki 1988; Kostrzewa 1990; Maslowski 1991; Tomaszewski 1993; Burszta 1997), how are they still present in my interlocutors' discourses today? Furthermore, what is the place of the body - as a locus where a sense of multiple belonging is produced and spatially inscribed? Questioning the ways of telling about and making family resemblances within a

1 My translation: par l'exil ou par le rêve est sans cesse hors de lui-même.

2 My translation: D'où viens-tu? - N'ayant pas saisi sa réponse, il insista: D'où ? Mais où ça se trouve? -En Europe, entre l'Allemagne et la Russie. Il réfléchit un instant puis, secouant la tête:-Ce n'est pas possible. Là-bas, il n'y a plus de place. - En effet, acquiesça-t-elle. - Et c'est bien de là que je viens. 
small number of families in Warsaw, I examine how a specific idea of "Polishness" is at the core of family narratives and produce an embodied experience of multiple borders and memories.

The concept of family resemblances used in this article was defined by Wittgenstein (1953): referring to language and games, Wittgenstein described some phenomena connected by a series of overlapping similarities. The central idea is that no single feature or set of features is absolutely common to all, but that similarities appear and disappear, just as the similarities between members of a family (build, features, eye color, gait, temperament, etc.) overlap and crisscross. The "games" - that is, practices, social interactions, and contexts - allow the likeness to rise to the surface.

The study of the representations at play in family resemblances was first developed within social science research on kinship (Malinowski 1930; Leach 1966; Rabain 1979; Vernier 1999). It shows a system of crossed transmissions, in which body likeness is passed on by the lineage opposite the lineage transferring power, wealth, and name; that is, by the mother in patrilineal societies, and the father in matrilineal societies.

Drawing on this genealogical approach, I suggest building on Halbwachs' works on the social frameworks of memory, together with Foucault's notions of technologies of the self (1988a). Similar to family or collective memory, resemblance is driven by combinative modes, selection, and re-composition processes. These processes arise from practical and sensitizing relays, which give fresh life to and transmit memory: images, gestures, voices, and smells, but also objects and materials - this "flesh of the world" (leib) produces and organizes likeness and difference, at the collective as well as family level. Family resemblance stands where the attainments of anthropology of the sensitive and works on memory meet, through the notion of embodiment (Csordas 1990, 1994; Taussig 1991) or embodied action (Warnier 1999), embodiment of material culture contributing to create a "sensory memory" (Sutton 1991), embodiment of long-term memory in a given community (e.g., through body techniques), and embodiment of others' bodies during daily exchanges. This notion of embodiment, breaking a simplistic and essentialist view on collective identity, contributes to a more dynamic, performative, and intersubjective understanding of belonging (Naoko Pilgrim 2001; Budgeon 2003; Narvaez 2006).

I began collecting the stories of families from very different social backgrounds in Warsaw in 2002, with the aim of understanding the extent to which family likenesses are in tune or dissonant. ${ }^{3}$ When asked about what constitutes the specificity of one family, the informants are driven to examine "what makes a Polish man or woman."

Nevertheless, the framework of the nation soon appeared to be very limitedly essentialist or rigid. My interlocutors were the spiritual brothers and sisters of two characters from

3 This research, based on the methods of participative anthropology, is a comparative ethnography between Warsaw and Rome. I engaged a small number of families, lived among them, interviewed them, and collected the life stories of various members of the household. This material is enriched with genealogical tools, data collection, and analysis of the elements of functional and material culture relaying memory transmission, such as objects, family photographs, video recordings, or personal diaries. 
Szczypiorski's novel, the engineer Muller (a man "German of body and Polish at heart") and Mrs. Seidenman (a good-looking Jewish widow, but Jewish "at the margin of her life, for Irma was fair haired and blue-eyed"; Szczypiorski 1988: 251). The two characters share an intimacy that almost seems to stem from the ironic discordance between the essentialist stereotypes carried about by appearances and the pluralistic interplay of allegiances composed by Szczypiorski’s novel.

Throughout this research, family resemblances emerged less as objects than as events, less as production than as practice. Somehow similar to collective memory, they are characterized by immanent, processual, and intersubjective production features. First, the immanent character of family resemblances means that one's way of being requires constant revitalization. These resemblances are always lived in the present tense, even when referring to deceased parents or stories in the past, because they imply an interpreter, here and now, to select, point out, and give flesh to meaningful signs. Second, they are processual - following Butler's gender analysis concepts (2004) - because they are done and undone, throughout time and despite the ceaseless transformations generated as time passes. They are regulators in ever-changing social relations, yet require the illusion of perpetuation to thrive. Third, resemblances are intersubjective: actors' bodies are not machines processing social metaphors, or blank pages waiting for outlines and identities to be inscribed on them: as a producer of culture, the body does more than simply convey representations. The study of family resemblances questions how actors embody, in their own flesh, and at the same time produce, systems of belonging.

\section{SENSITIVE MEMORIES}

I suggest that family resemblances are a point of departure for studying sensitive memories, multiple as the meanings of this expression may be. Literally, these memories constitute a sensorial matrix, mixing elements of a common material culture, and generating proximity, distance, multiple identifications, or ways of being oneself. Such a process points to resemblances as a body technique, according to Marcel Mauss. Promiscuous bodies, contagious moods, and the sharing of everyday life's circulating gestures and things produce and shape idiosyncratic yet collective beings (see also Crocker 1977 on Bororo). Such an approach is in line with the "sensory profile" (Howes 1991), "tactile mimesis" (Taussig 1991), the "sensory order" (Classen 1993), "perception as material culture" (Serematakis 1994), and the history of the researcher's body "sensorium" (Duden 2002).

This body can be experienced; for instance, in the realms where a common sensitive culture is constructed (the kitchens I have visited, imbued with sensorial imprints, come to mind). Such places, impressed with their very own sensorial quality, mould different bodies and individuals. They compose spaces in which to be oneself - like a foot resting in the slipper it has given shape to - but also spaces where tenderness, surveillance, desire, control, and violence can be exerted on others' bodies (Gurney 2000). Yet this body can 
also be remembered - a matrix resonant with sounds provides depth and breadth to recollections, and creates a new matrix of recognition.

Furthermore, the adjective sensitive echoes a dimension of vulnerability, putting forward painful events, scars in history. Sensitive memory is a wounded memory. Naming the absent, filling in genealogical gaps, and locating forgotten villages is an art bestowed upon those that make every effort to pass on the memory of the family. "Polish Poland is somehow an absence of a place and a place of absence, where the blur of intergenerational narratives thickens even more the intertwining of national borders"4 (Eizner and Szurek 1990: 41). Every so often, the experience of war gives ground to the family myth, and its resonance in the community at large is nothing but one amplified heartbeat.

Poland experienced one of the "twentieth-century totalitarian regimes that revealed a danger unsuspected until then: the erasing of memory... Such tyrannies not only systematized the stranglehold on memory, but extended their control down to the innermost corners" (Todorov 1995: 9-10). As a consequence, memory undoubtedly gained tremendous political clout, any act of reminiscing thereby crowned with anti-totalitarian resistance. Under Wałęsa's government, the creation of a National Institute for Memory marked the fall of the communist regime. Accordingly, in other Soviet bloc countries the "whisper of memory" (Nora 1997) grew into polyphony, and sometimes a deafening cacophony. As the great communist narrative came to an end, a multiplicity of memories claimed a legitimacy of their own, asserting heterogeneous and possibly conflicting viewpoints, and calling on new actors to enter the social stage.

Aside from official memory - fostered by collective effort and imprinting history's rediscoveries, rewriting of schoolbooks, and redefinition of urban space - family memory weaves collective events with personal tragedies, casting individuals within a social group and simultaneously singling them out (Halbwachs 1925). In such a historical context, punctuated with military occupations, shifting borders, and forced migrations, memory transmission has been a potent instrument of identity building: being Polish resulted from the construction and dissemination of a concurrent memory kept inside kinship, contrasting with the memory of temporary invaders. Anna Sawisz (1990) studied how the images conveyed by family memory during the communist era produced alternatives to the images of self-justification provided by the authorities of the day, thereby resisting official history. Noticeably, discussions with children cleverly orchestrated the data on Poland's history together with family narratives, the latter mitigating the perceived deficiencies in the school curriculum. ${ }^{6}$

4 My translation: La Pologne polonaise est en quelque sorte une absence de lieu et un lieu de l'absence, dont le plan et l'entrelacs des contours nationaux sont accentués par le flou des récits entre générations.

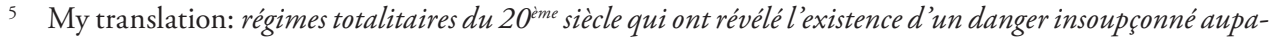
ravant: celui de l'effacement de la mémoire... Ces tyrannies ont non seulement systématisé leur mainmise sur la mémoire, mais ils ont voulu la contrôler jusque dans les coins les plus secrets.

6 On the articulation between family and collective memory in contemporary Poland, see also the very complete work of Kwiatkowski (2008). 
I therefore suggest that reflecting on resemblances is an accurate approach to deciphering processes of belonging in a context of great uncertainty: it articulates naturalization rationales or historicization of belonging on the one hand, and family and collective memory transmission on the other hand, throughout the elaboration of what resembles or reassembles.

\section{FLESH, GENDER, AND BLOOD: EMBODIED BELONGINGS}

Narratives about family likeness, when considering the transmission of national belonging, show how central the mother is, and above all the grandmother, in the recollection of collective and family ups and downs. Whereas genealogies highlight an undifferentiated, cognatic, system at the bottom, the parenthood vocabulary is heavily gendered and there is an imbalance between the mother's and father's sides. Household unity is maintained in particular around the grandmother, who enables forms of long-term or on-off cohabitation, and produces a strong hierarchy among generations.

The maternal grandmother is the central figure in family and collective memory transmission. Such centrality is based on a system of practical relays: organizing the house, running the errands, and taking care of the children. This focus on maternal relays takes on a particular significance in light of Poland's history, insofar as these hardworking grandmothers recalled by my informants echo a contemporary version of the matka bohaterska 'heroic mother', a figure of Polish romantic mythology that, in times of exile or foreign occupation, contributed undercover to the propagation of language, culture, and religion. By keeping her function, she maintains society's existence, physically and spiritually, as memory and traditions are perpetuated.

Women have always actively participated in Polish nationalism, in its romantic as well as its pragmatic and positivist accounts. Even though they directly took up arms against a succession of invaders, women were nevertheless mostly involved in "motherly" tasks: supplying arms, clothes, and food, collecting and transmitting information, taking care of the wounded, keeping the household finances straight, and, above all, transmitting memory through children's education (Laurence-Kot 1992). Such female activism, taking root on the reinforcement of gender positioning, is closely related to the emergence of nationalism, according to George Mosse (1985) or Lynn Hunt (1992). This quest for permanence through a female figure takes on a peculiar shade in Poland because the heroic mother is the main actor in the learning process of being Polish, never obvious and always to be defined again: "without an educational system able to communicate to every citizen a sense of belonging and identifying to the national community, nineteenth-century Polish people would never have naturally assimilated their Polishness, which then was seen as a task to fulfill dutifully" (Jarzebski 1993: 25).7 The matka bohaterska is the most durable

My translation: en l'absence d'un système d'éducation qui eût inculqué à tous les citoyens le sentiment 
personification of the national spirit, accomplished in action, ceaselessly swinging from pride to contempt, and staving off the risks of identity disappearance or violent revival. The strong, heroic mother making up for missing men, passing on to children the sense of national affiliation through language and religion, is still alive in contemporary Poland. This is seen, for instance, in women's involvement in the Solidarność trade union, as studied by Kristi Long, which demonstrates the success of their protests and their ability to exist as a group (e.g., the "litanies of food"; Long 1995: 49).

The importance of women for memory transmission and group continuity is also at stake outside the household and the nourishing function. The very "essence" of Polishness transmitted in this way articulates gendered consideration because gender differences and national belonging are naturalized in a joint process. In the case of Iwona:

Interviewer: which character do you think is really transmitted from one generation to the other?

Iwona: Women's ingeniousness; all the women in our family are resourceful, creative, tough, strong, aren't they? (She turns to face her "sister," stressing her words with her fist clenched.) They are determined...

Ewa: ... and smart even ...

$\ldots$

Iwona: Right. We are so strong, we are no kokotki ('chicks') [here she shifts from the third person to the first person plural, thereby including herself in the group of women of the family - "family" here means the maternal side], we are hateful.

Ewa: Yes, our blood is mean, terrible.

A modicum of inescapability taints the bloodline that runs through the generations and lays the foundation, on the mother's side, for a matrix of recognition. Deriving from it is a restricted exchange scheme, in which marriage between maternal cousins is prohibited because they are considered to share "the same blood," as Jan, a fifty-one-year-old engineer, and Hanna, a twenty-seven-year-old theology student, told us.

The female body produces and reproduces a grid of identifications and prohibitions made of fluids, thereby setting up a model of Polishness. There is a gendered variation of taking part in the nation: a specific male way and, noticeably, a female way. When I first engaged Tadeusz, a fifty-one-year-old pre-retirement army officer, to tell me his family story, he took three photographs out of a box: one of his paternal grandfather, one of his father, and one of himself, the three of them wearing army uniforms. The pictures are displayed in chronological order, showing the grandfather first and the informant at the end. Three generations under

d'identification et d'appartenance à la communauté nationale, la polonité au $19^{i m e}$ siècle n'était pas quelque chose que les Polonais auraient acquis d'une manière naturelle; cette polonité étant perçue en tant que devoir ou tâche à accomplir.

8 All the cousins interviewed in Warsaw call each other "brother" or "sister" by way of their aunt or uncle, and so a cousin may be a brat cioteczny if he is the son of an aunt. Only in one family did the father and godfather of a child call each other "brother." 
one name, one gender, and one line of work; the three uniforms belonging to different armies, possibly from opposing nations - as described in the novels of Hanna Krall or Kazimierz Brandys. Yet the continuity linking these three men challenges the photographer's lens. On the women's side, however, the following remark by a retired education professional puts forward an inclusive "we" referring to both the family and the national community: "We are not the kind of women to say chéri, chéri [in French], us, we've always worked. Yet men like women that stand there doing nothing, admire them and tell them 'you are so handsome and so brave" (Zosia, 70 years old).

The use of a French word highlights, by contrast, a national and Eastern specificity, just like the word kokotki used by Iwona and Ewa. Jula's mother declares she is proud of her nine-year-old daughter's Russian features, "tough and strong genes" still visible despite the mixing of many generations. My landlord, age 47, justifies her daily workout by the need to build an armor of muscles, "an iron body, like the Russians." This glorification of the Eastern legacy was unthinkable during the Popular Republic era; it emerged with post-communist society in a double opposition towards an outer model and the exacerbated will to be true to oneself. The body is a tool used to reject or claim that distinction involves a demand to refuse to give in to standardization, to claim the freedom to differ from the main models, mostly foreign. Another manifestation of this "frenzied bond with freedom, insane, unapologetic" leads to defining oneself as always "against" or "in opposition to" (Konwicki 1988: 108).?

For the foreign observer, the East/west tension takes shape in the gap separating intimacy (where the Eastern legacy prevails, in its somehow stereotyped aspects) and public spaces (referring to an idealized Western reference). It has been twenty years since the fall of the communist regime in Poland, yet Warsaw is still a huge construction site. Nothing stands like "before": the names of places, of the country itself, and the national symbol, the monuments, the national calendar, and public holidays. The urban landscape has changed to make way for finance institutions. Each political, economic, or social change seems to be molding a new city, covering the small souvenirs, whose authorized remains are walled within the private realm. The collective body, as it is narrated through family likeness, is a concrete extension, and sometimes the "reverse side" of this spatial inscription of plural and often conflicting memories (Diasio 2007).

\section{MINORITY NOSTALGIA: THE "ORPHAN PEOPLE"}

There is a sharp contrast between the biological link - a seemingly continuous bloodline running through the generations - and family backgrounds marked by migrations and the melting of populations. Wars, forced migrations, and separations put narratives under

9 My translation: cet attachement forcené, insensé, effréné à la liberté" qui conduit à se définir toujours "contre" ou "en opposition à. 
the aegis of mobility: the re-construction of a family story goes hand in hand with one's effort to give vivid texture to the places one comes from, the various steps one went through (which are often visible in common genealogies), the place where various members of the family arrived, and the story of the house. Such mobility is not purely geographical; it also penetrates linguistic and religious realms: each individual bears readable landmarks, which differentiate him or her from the various populations making up the country. Thus, speaking about family likeness, an informant says:

I don't know if the Russians really have characteristic features, the Poles are such a mixed nation, so many people have been here, isn't that right, and the Russians, and the Turks, and the Tatars, and the Germans, it's a mixed nation, strong, and so the typical Polish woman isn't at all a blonde with blue eyes, is she, instead she's a woman with brown hair and grayishgreen eyes. This account is all the more interesting in that it is Iwona's, the school teacher that strongly asserts that blood is the central element in the transmission of attachments. She pushes the interpretation further, and when drawing the portrait of the "typical Polish women" she is talking about herself. The nation corresponds here to an ethnic group - the Catholic Pole that, as Zawadzki showed, was reinvented by postwar tradition - and takes root in a specific relationship to the state:

In Eastern Europe societies, history marked by imperial domination and the loss or weakness of state institutions, the national community often referred to a culture or a religion, and not to a set of rights and duties linking citizens to the state: ... access to legal rights in full is hence less perceived in connection to citizenship than to a supposed native nationhood. (Zawadzki 1997: 114) $)^{10}$

Iwona's double discourse - blood transmitting identity and value given to inter-ethnic mixing - tells in itself the actual paradox of a state without minorities, yet keeping faith in the memory of a multicultural Poland.

Before the war, different people lived together in Poland: Poles, Jews, Germans, Ukrainians, Belarusians, Tartars, Armenians, Lithuanians, and so on. Poland's history and culture are a product of such coexistence. Since the end of the war, only one population lives in Poland; the country is now a state without minorities: they were slaughtered, deported, or displaced. Polish culture is now made up of a population that has to live alone. Polish

10 My translation: Dans les sociétés est-européennes, historiquement marquées par les dominations impériales et par la perte ou la faiblesse de leurs structures étatiques, le lien national fut souvent pensé par référence $\grave{a}$ une culture ou à une religion, et non pas comme un ensemble de droits et de devoirs liant le citoyen à l'Etat:.. l'accès à la plénitude des droits y est donc moins perçu comme dépendant de la citoyenneté que de l'appartenance à une nationalité supposée autochtone. 
people are not really conscious of being orphans, although each Pole carries

the nostalgia of these minorities in him. (Szczypiorski 1988: 274) $)^{11}$

This unnamed feeling of loss appears in most of the accounts gathered. Some of my informants are descendants of wypedzony 'eastern territory deportees', people that were forced into migration from what is now Belarus and Ukraine. Some were dispatched to lands and houses that were inhabited in the past by other wypedzony, German-speaking minorities pushed aback beyond the Oder-Neisse line at the end of the Second World War. Others reached Warsaw, abandoning the countryside. All of them are doubly regretful. The first regret is their connection to the land. A land trampled by foreigners, lost, gained back, and abandoned to urbanization is evoked with shivers in the voice and almost sensuous tones, like the image of Elżbieta's ancestor, who was made a Russian soldier against his will, deserted the army so as not to fight his own people, and embraced the land when stepping out of the train. The second regret, in the words of an informant calling to mind her maternal grandmother's village in Ukraine, is that "in one village the parish church, an orthodox church, and a synagogue could stand close together."

Memories rewrite history, creating a family narrative and a national mythology taking root in the archetypal village and the nostalgia of a bygone past. Such a myth strengthens a sense of common belonging that could save interpersonal and intercommunity bonds, outside the political reach of the state. The family facet, entrenched in the myth of the other Europe, gives concrete existence to the ideal of Respublica, ${ }^{12}$ a meeting point of languages and cultures thriving beneath the national level. However, family constitutes the matrix of a zealous desire to live among one's own group, excluding any foreign element in the name of "bio-cultural homogeneity." Both cases question the very existence of a state that would be able to regulate and sustain the relationships between what is considered other and what is considered one own. Following Zawadzki: "a Polish nationalism aspiring to establish a Nation-State, and not a State-Nation, would contribute to weaken the latter" (Zawadzki 1997: 116). This would be detrimental to legal procedures and oppose the population's deep-rooted desires, as field studies and surveys on the importance of the Church in Polish society show.

11 My translation: Avant la guerre, plusieurs peuples cohabitaient en Pologne, des Polonais, des Juifs, des Allemands, des Ukrainiens, des Russes Blancs, des Tartares, des Arméniens, des Lituaniens ... L'histoire et la culture polonaise résultent de cette coexistence. Depuis la fin de la guerre, un seul peuple vit en Pologne; cepays est aujourd' hui un Etat sans minorités: elles furent massacrées, déportées, déplacées. La culture polonaise actuelle est celle d'un peuple qui doit vivre seul. Les Polonais n'ont pas réellement conscience d'être orphelins. Mais chaque Polonais porte en lui la nostalgie de ces minorités.

12 The Polish noble republican ideal, in which various populations peacefully coexist, is based on the sacredness of the land and nature. It embodies the myth of the other Europe in Polish literature, Czesław Miłosz's writings in particular. 


\section{CONCLUSION}

The end of totalitarianism in Poland signaled a "tiger leap towards the past" (Benjamin 1982: 84). In the years after 1989, books on history were actual best-sellers. A more qualified and diversified historical consciousness emerged, focusing not only on the double occupation of Poland by the Nazis and the Soviets, but also reminiscing about the presence of Jews in Poland and the expulsion of the Germans at the end of the Second World War, and referring to the debate on ethnic and religious minorities' fates before 1939 and after 1945. According to Ziolkowski, however,

The radical break of the continuity of settlement and break of historical tradition (both in West and former East) have produced a very peculiar and highly selective memory of the past. On the one hand, there exists fairly good knowledge of some historical facts; on the other, there is historical ignorance and cultural amnesia as regards both Polish memory of the German presence in today's Poland and Poland's Eastern neighbours' memory of Polish presence and accomplishments in the territory of modern Ukraine and Belarus. (Ziolkowski 2000: 304)

I argue that the cultural amnesia described by Ziolkowski has more to do with a way of looking away, and ultimately contributes to diversifying the representations of Poland. The genealogical narratives collected within the household - evoking the Eastern frontier threshold, border shifts, and forced migrations - are central to the family myth because they keep the nostalgic ideal of a multilingual and multicultural Poland alive. Observation from afar is nourished by the diversity and the hardships that constitute the family story. In contrast, when informants are asked to shift their gaze from the family circle to the national level, memories dissolve into comments about the country's fragile sovereignty falling prey to foreigners from the inside.

These observations are in line with Szacka's study of collective memory transmission within a Polish family from 1965 to 2000. As time goes by, the conception of a community brought together through culture, sciences, and the arts wanes and makes room for the image of a powerful state, independent and ready to resort to the force. Such an image appeals to "strong" characters, and substitutes for a conception of a community sharing the same values. The data collected by Szacka show that images of Marshal Piłsudski prevailed during the post-communist transition. Monuments to the marshal reappeared in the public space with the end of the communist era, bringing along elements of continuity as national history and Polishness were redefined.

The affirmation, through current public images, of Poland as a powerful and independent nation seems out of phase with the perception of Poland transmitted and told in the realm of the household, referring to a transitional nation, made of margins and steps. The former calls for political legitimacy, whereas the latter echoes identity issues; these 
two contrasting rationales seldom coincide in a country that largely asserted itself outside, and even against, the state.

Family narratives on inheritance and family resemblances in Warsaw shed a pluralistic light on how people find their own place. There are no normalization strategies at the family or even social level, but the country's historical hiccups, past religious and ethnic diversity, and the ebb and flow of borders are embodied and valued, depending on the context. All of these variables are performative tools enabling people to differentiate themselves or become themselves. My interlocutors are constantly swinging between their need for recognition and what Lévi-Strauss (1972: 52) called "the refusal of compelled identifications". The body produces, makes thinkable, and performs those paradoxical behests. The question is not about standing "between East and West" but rather about being "within East and West."

Women are crucial in the never-ending process of transmitting Polishness. The naturalization of gender and community differences thus coexist with a persistent imagery, sustained by family memory, and relating to a multilingual and multicultural Poland.

Ultimately, the case of Poland is a striking example of the identity paradox that stands at the heart of the European unification process: how should propinquity and a unifying project be built out of differences and segmentation that can border on conflicting family, community, local, national, and supra-national loyalties? How should one cope with the "identitary illusion" (Bayart 1996) in everyday life? Nevertheless, "when relating to the other, withdrawing to national or local entities on the one hand, and building an integrated Europe on the other hand, accommodates an alternative between openness and closure, the bridge or the door, according to Simmel” (Sanchez-Mazas, Van Huskkerken and Gély 2005: 310). ${ }^{13}$ The narratives by Warsaw families remind us that such oppositions should be handled with caution, and prevent a unique interpretation of history, experiences, and concepts.

\section{REFERENCES}

Bayart, Jean-François

1996 L'illusion identitaire. Paris: Fayard.

Benjamin, Walter

1982 Angelus Novus: Saggi e frammenti. (Trad. it. Schriften). Torino: Einaudi.

Budgeon, Shelley

2003 Identity as Embodied Event. Body and Society 9 (1): 35-55.

Burszta, Wojciech J.

1997 Dwie Europy, In: Mucha J. and W. Olszewski (eds.), Dylematy tozsamosci europejiskich pod koniec drugiego tysiacelecia. Torun: Unywersytet Mikolaja Kopernika, 37-84.

13 My translation: si les replis nationalistes et régionalistes, d'une part, et la construction d'une Europe intégrée d'autre part, laissent figurer le rapport à l'autre en terme d'alternative entre l'ouverture et la fermeture, le pont ou la porte, selon Simmel. 
Butler, Judith

2004 Undoing Gender. New York and London: Routledge.

Classen, Constance

1993 World of Senses: Exploring the Senses in History and Across Cultures. London: Routledge.

Crocker, Chris

1983 Les réflexions du soi (The Mirrored Self, 1977). In: Lévi-Strauss, Claude, L'identité. Paris: PUF, $157-184$.

Csordas, Thomas J.

1990 Embodiment as a Paradigm for Anthropology. Ethos 18: 5-47.

Csordas, Thomas J. (ed.)

1994 Embodiment and Experience: The Existential Ground of Culture and Self. Cambridge: Cambridge University Press.

Diasio, Nicoletta

2007 Des fleurs et des pierres: Mémoires et morts dans l'espace public en Pologne. Frontières (Lepolitique et la mort) 19 (1): 69-73.

Duden, Barbara

2002 Die Gene im Kopf-der Fötus im Bauch: Historisches zum Frauenkörper. Hannover: Offizin-Verlag.

Eizner, Nicole et Jean-Charles Szurek

1990 Sous le regard des autres. Wallon, E. (dir.), Pologne: Dernières nouvelles de l'Atlantide = Autrement $47: 41-46$.

Foucault, Michel

1988a Technologies of the Self. In: Martin, L. H., H. Gutman and P. Hutton, Technologies of the Self: A Seminar with Michel Foucault. Amherst, MA: The University of Massachusetts Press, 16-49.

1988b The Political Technology of Individuals. In: Martin, L. H., H. Gutman and P. Hutton, Technologies of the Self: A Seminar with Michel Foucault. Amherst, MA: The University of Massachusetts Press, $145-162$.

Gurney, Craig M.

2000 Accomodating Bodies: The Organization of Corporeal Dirt in the Embodied Home. In: McKie, L. and N. Watson, Organizing Bodies: Policy, Institutions and Work. London and New York: McMillan-St.Martin's Press, 55-78.

Halas, Elzbieta

2000 Transformation in Collective Imagination. Polish Sociological Review 3 (131): 309-322.

Halbwachs, Maurice

1994 (1925) Les cadres sociaux de la mémoire. Paris: Albin Michel.

Howes, David (ed.)

1991 The Varieties of Sensory Experience: A Sourcebook in the Anthropology of Senses. Toronto: University of Toronto Press.

2003 Sensual Relations: Engaging the Senses in Culture and Social Theory. Ann Arbor: University of Michigan Press. 
Hunt, Lynn

1992 The Family Romance of the French Revolution. Berkeley: University of California Press.

Jarzebski, Jerzy

1993 L'auto-définition des Polonais. In: Tomaszewski, M., Pologne singulière etplurielle: La prosepolonaise contemporaine. Lille: Presses Universitaires de Lille, 23-38.

Konwicki, Tadeusz

1988 (1977) Le complexe polonais (Trad. fr. Kompleks polski). Paris: Laffont.

Krall, Hanna

1994 (1989) La sous-locataire (Trad. fr. Sublokatorka). Marseille: Ed. de l'Aube.

Krauze, J .

1990 En Pologne, c'est-à-dire partout. In: Wallon, E. (dir.), Pologne: Dernières nouvelles de l'Atlantide = Autrement 47: 12-18.

Kostrzewa, Robert (ed.),

1990 Between East and West: Writings from Kultura. New York: Hill and Wang.

Kwiatkowski, Piotr Tadeusz

2008 Pamiec zbiorowa spoleczenstwa polskiego w okresie transformacji. Warszawa: Scholar.

Lévi-Strauss, Claude

1972 Anthropologie structurale II. Paris: Plon.

Lorence-Kot, Bogna

1992 Konspiracja: Probing the Topography of Women's Underground Activities. The Kingdom of Poland in the Second Half of the $19^{\text {th }}$ Century. In: Jaworski, R. and B. Peitrow-Ennker (eds.), Women in Polish Society. London and Boulder: Eastern European Monograph.

Leach, Edmund

1968 (1966) Critique de l'anthropologie. Paris: PUF.

Long, Kristi S.

1995 Mothering Solidarity: Maternal Imagery and Activism. Ethnologia Polona 19: 39-52.

Malinowski, Bronislaw

1970 (1929) La vie sexuelle des sauvages du nord-ouest de la Mélanésie. Paris: Payot.

Maslowski, Michel (dir.)

1991 L'Europe du milieu. Nancy: PUN.

Mauss, Marcel

1993 (1934) Les techniques du corps. In: Mauss, M., Sociologie et anthropologie. Paris : PUF, 363-386.

Milosz, Czeslaw

1964 Une autre Europe. Paris: Gallimard.

Mosse, George L.

1985 Nationalism and Sexuality. Madison and London: University of Wisconsin Press. 
Naoko Pilgrim, Anita

2001 Performance and performative. Body and Society 7 (4): 87-96.

Narvaez, Rafael F.

2006 Embodiment, Collective Memory and Time. Body and Society 12 (3): 51-73.

Nora, Pierre

1997 Les lieux de mémoire: La République. (Tome I.) Paris : Gallimard.

Rabain, Jacqueline

1979 L'enfant du lignage: Du sevrage à la classe d'âge chez les Wolof du Sénégal. Paris: Payot.

Sanchez-Mazas, Miguel, F. Van Humskerken et R. Gély

2005 La citoyenneté européenne et l' “Autre du dedans". In: Sanchez-Mazas, M. et L. Licata (dir.), L'Autre: Regards psychosociaux. Paris: PUF, 309-336.

Sawisz, Anna

1990 Transmisja pamięci przeszłości. In: Szacka, B. and A. Sawisz, Czas przeszty i pamięć spoteczna. Warszawa: IS-UW, Scholar, 121-198.

Serematakis, Constantina Nadia (ed.)

1994 The Senses Still: Perception and Memory as Material Culture in Modernity. Chicago: University of Chicago Press.

Stoller, Paul

1989 The Taste of Ethnographic Things: The Senses in Anthropology. Philadelphia: University of Pennsylvania Press.

Sutton, David E.

2001 Remembrance of Repasts: An Anthropology of Food and Memory. Oxford and New York: Berg.

Szacka, Barbara

1990 Społeczna pamiec polskiej przeszlosci narodowej w latach 1965-1988. In: Szacka, B. and A. Sawisz, Czas przeszty i pamięć spoteczna. Warszawa: IS-UW, Scholar, 8-120.

Szczypiorski, Andrzej

1988 (1986) La Jolie Madame Seidenman (Trad. fr. Poczatek.). Paris: Ed. Fallois-L'Age de l'Homme.

Taussig, Michael T.

1991 Mimesis and Alterity: A Particular History of the Senses. New York and London: Rutledge.

Todorov, Tzvetan

1995 Les abus de la mémoire. Paris: Arléa.

Tomaszewski, Marek (dir.)

1993 Pologne singulierre et plurielle: La prosepolonaise contemporaine. Lille: Presses Universitaires de Lille.

Turner, Victor W.

1987 The Anthropology of Performance. New York: PAJ.

Turner, Victor W. and Edward M. Bruner

1986 The Anthropology of Experience. Urbana and Chicago: University of Illinois Press. 
Vernier, Bernard

1999 Le visage et le nom: Contribution à l'étude des systèmes de parenté. Paris: PUF.

Warnier, Jean-Pierre

1999 Construire la culture matérielle: L’homme qui pensait avec ses doigts. Paris: PUF.

Wittgenstein, Ludwig

1953 Philosophische Untersuchungen. Oxford: Basil Blackwell.

Zawadzki, P.

1991 La dimension communautariste de l'antisémitisme en Pologne. In: Masłowski, M. (dir.), L’Europe du milieu. Nancy: PUN, 139-155.

1997 Transition, nationalisme et antisémitisme: L'exemple polonais. In: Birnbaum, P., Sociologie des nationalisms. Paris: PUF, 103-119.

Ziolkowski, Marek

2000 Four Functions of Memory. Polish Sociological Review 3 (131): 291-308.

\section{UTELEŠANJE MEJ IN UPRIZARJANJE NASPROTUJOČIH SI IDENTITET V NEKJ DRUŽINSKIH PRIPOVEDIH NA POLJSKEM}

Razpravo o položaju in identiteti dežele, kakršna je Poljska, je pogosto obvladovalo vprašanje o srednji Evropi med Vzhodom in Zahodom. To "zarisovanje četrti "je bilo včasih obravnavano bodisi kot kontroverzno, včasih neprimerno, kdaj drugič kot srce poljskega mita in duhovne in fizične geografije mej. Nejasnost in večpomenskost teh oznak ustrezata globljemu problemu, ki zahteva nadalinji premislek.

Članek predstavlja antropološko raziskavo družinskih pripovedi o spominu in posredovanju $v$ Varšavi. Analizira položajne identitete, kakor nastajajo $v$ družbenih telesnih praksah: kako utelesiti spomine in identiteto in kako jih rekonstruirati v družinskem življenju tako, da sledimo različnim družbenim okoliščinam. Osrednji koncept, ki povezuje spomin in utelešenje, so "družinske podobnosti", kakor jih je opredelil Wittgenstein leta 1953.

Etnografska raziskava je bila opravljena v majhnem številu poljskih družin v Varšavi s pomočjo genealogij, družinskih pripovedi, udeleženskega opazovanja, intervjujev z več člani iste družine, analizo telesnega dela in snovne kulture v vsakdanjem življenju. Metodologija je dopuščala spraševanje o načinih, kako so upovedene in ustvarjene družinske podobnosti. Ta koncept je vstopna točka za razvozlavanje procesov pripadnosti v okoliščinah splošne negotovosti: družinske podobnosti namreč izražajo naturalizacijo načel ali zgodovinjenje pripadnosti na eni strani ter družinsko in kolektivno posredovanje spomina na drugi-z iztanjševanjem tega, kar je podobno ali znova povezuje. Premislek o podobnostih je tudi natančen prijem za obravnavo čutnih spominov, ki so večplastni - tako kakor pomeni samega izraza. Dobesedno ti spomini ustvarjajo čutno matrico $z$ mešanjem elementov skupne snovne kulture in ustvarjanjem bližine, razdalje, več različnih identifikacij ali načinov biti jaz. Genealoško posredovane ženske dejavnosti in žensko sorodstvo so odločilne v nikoli-dokončanem procesu graditve "poljskosti«. Vendar naturalizacija spola in 
razločkov med skupnostmi soživi v dolgotrajnem imaginariju, ki ga podpira družinski spomin in je povezan z večjezično in večkulturno Poljsko. Genealoške pripovedi, ki so bile zbrane v gospodinjstvu - in kličejo v spomin prag vzhodne meje, premikanje meje, prisilne selitve - so osrednjega pomena za družinski mit, saj vzdržujejo nostalgični ideal "Poljske manjšin".

Družinske pripovedi o izročilu in družinskih podobnostih v Varšavi so večsmerno osvetlile, kako ljudje najdejo svoj kraj. Kažejo, da na družinski in celo družbeni ravni ni normalizacijskih strategij, temveč so, odvisno od konteksta, zgodovinski padci dežele, pretekla verska in etnična raznovrstnost, padanje in potek meja bolj utelešeni in vrednoteni. Vse te spremenljivke so performativno orodje, ki ljudem omogoča, da se razločujejo med seboj ali postajajo "jaz", bodisi da so bolj "vzhodni" ali "zahodni", ko sledijo identitetnim strategijam in družbenim razmeram. Informatorji nenehno kolebajo med potrebo po priznanju in tem, kar je Lévi-Strauss (1972: 52) imenoval "zavračanje prisilnih identifikacij". Telo ustvarja, naredi mišljeno in uprizarja te paradoksne zahteve. Vprašanje ni stati "med Vzhodom in Zahodom", temveč bolj v biti "na Vzhodu in Zahodu«.

Dr. Nicoletta Diasio, Laboratoire Cultures et Sociétés en Europe (CNRS/UdS), Université de Strasbourg,nicoletta.diasio@misha.fr 